\title{
OBSCENITY AND THE MAIL: A STUDY OE ADMINISTRATIVE RESTRAINT
}

\author{
Edward de GrazIA*
}

The United States may give up the Post Office when it sees fit; but while it carries it on, the use of the mails is almost as much a part of free speech as the right to use our tongues. ...

-Holmes, J., dissenting, in United States ex rel. Milwaukee Pub. Co. v. Burleson, 255 U.S. 407,437 (I92I).

The United States Post Office Department enjoys the dubious distinction of being the only governmental agency, federal or state, fully empowered to censor ${ }^{1}$ obscene literature and art. ${ }^{2}$ This power derives from the federal monopoly over the mails, ${ }^{3}$ and its exercise is directed by a small group of men in Washington, D. C., whose moral sensibilities, thus, can effectively determine both what we may read and whether most newspaper, magazine, and book publishers in the United States may operate. It is with the powers and procedures, standards, and rationales employed by the postal authorities in their exercise of this far-reaching power that this paper is concerned.

\section{I}

\section{Powers and Procedures \\ A. Seizure and Exclusionary Powers}

The postal censorship system appears to function, more or less, as follows:

Any mail that may be opened for inspection (all but first class mail) ${ }^{4}$ may be in-

*A.B. 1948, J.D. 195x, University of Chicago. Member of the District of Columbia and United States Supreme Court bars; member of the firm of Kirkland, Fleming, Green, Martin \& Ellis, Washington, D. C.; counsel for American Civil Liberties Union in several postal censorship cases. Contributor to lay and legal periodicals.

The author wishes to express his sincere appreciation to Mr. Abe McGregor Goff, Solicitor of the United States Post Office Department, and to Mr. Saul Mindel, of the Solicitor's Office, who, although aware of the author's prejudices, nevertheless, cooperated fully with him and supplied much of the information about the postal censorship system that appears in this article.

I The terms "censor" and "censorship," as used here, imply prior restraint-a concept anathematized in the classic literature concerning freedom of expression. See, e.g., 4 BL. Comm. "15I-53.

${ }^{2}$ Among other federal instrumentalities, only the Customs Burcau of the Treasury Department is authorized to seize and detain matter conceived to be obscene-but only "to await the judgment of the district court," which is empowered to determine whether the apprehended matter is obscenc, upon which issue, a trial by jury may be had upon request. 46 STAT. 688 (1930), I9 U.S.C. \$1305 (1952 Supp.). On the state and local level, there are no long-standing censorship boards for literature, although one state and a number of cities have already authorized them. Sec Lockhart and McClure, Literature, the Law of Obscenity, and the Constitution, $38 \mathrm{MrNN}$. L. Rev. 295, 31 I (1954). And although all states except New Mexico have statutes prescribing punishment, after the fact, for publication or disscmination of obscene literature, these statutes probably do not pose as great a threat to free expression as would censorship statutes, which, by definition, prohibit publication in the first instance.

${ }^{3}$ See Ex parte Jackson, 96 U.S. 727, 729 (1877).

"First class mail cannot be opened or inspected by the Post Office Department, such action having early been held to constitute an illegal search and seizure in violation of the Fourth Amendment. Ex parte Jackson, supra note 3 . 
spected for "obscenity" by any mail clerk in any post office and by any mail carrier on any route." If any such inspector believes its contents-be it book, magazine, newspaper, pamphlet, photograph, film, or advertising circular-to be obscene, it will be refused; or, if it has been accepted, it will not be delivered. Where the mail has been intercepted rather than rejected, as is more often the case, it is transmitted, over the signature of the local postmaster, to the Solicitor for the United States Post Office Department, at Washington, D. C., for review of the decision that it is obscene. At the Solicitor's office, the "obscene" character of the mail is weighed by one or more of several persons working on these matters, who then mark the offending passages and make recommendations which are, in turn, reviewed by the Solicitor (or Assistant Solicitor), who makes the final decision-one imputed in law to the Postmaster General. If the mail is, in this fashion, finally found to be not obscene, it will be returned to the local post office with instructions to the postmaster that it be forwarded to the addressee-and neither the addressor nor the addressee may ever know of the misadventure. If the Solicitor decides that the mail is obscene, however, the local postmaster will be instructed to notify the addressor that his mail has been intercepted, and that unless he "show cause" within fifteen days why the matter should not be disposed of as "non-mailable" matter, it will ultimately be burned. ${ }^{6}$ In such a case, the "show cause" notice, which may follow the act of seizure by many weeks, may be the first advice to anyone that mail in transit had been seized.

The conduct by the Post Office Department of this obscenity censorship function is characterized by informality. There are no rules or regulations, duly promulgated and posted by the Department in the Federal Register or codified in the Code of Federal Regulations, that disclose the procedures by which "obscene" mail is handled or that apprise owners or other interested persons of their rights with regard to such matters. No hearing of any kind familiar to judicial or administrative due process is ordinarily, at any time, held. If, however, an interested party threatens or acts to sue the Postmaster General or his agents, such person may receive notice from the Solicitor that a "hearing" on his mail has been scheduled. "The value of any such subsequent hearing before the Department is dubious, however, since the mail has already been seized, the Solicitor has already determined it to be obscene, and the functions of "prosecutor" and "judge" merge in the Solicitor. Resort to the courts offers greater promise of relief. 8

\footnotetext{
- The Post Office Department also employs postal inspectors who actively investigate instances of suspected transmission of obscene matter through the mails-chiefly through the device of ordering and purchasing such matter under fictitious names.

"Although obscene mail is supposed to be so destroyed, in the same manner as "dead letters," there is some doubt as to whether such disposition is uniformly made. Preferable would seem to be the practice of the customs authorities, who transmit confiscated material to the Library of Congress for reference by scholars and other "legitimately" intercsted persons.

${ }^{7}$ This was the case, for example, in Sunshine Book Co. v. Summerfield, 128 F. Supp. 564 (D.D.C.), aff'd, 22 I F.2d 42 (D.C. Cir.), cert. denied, 74 Sup. Ct. 661 (1955).

${ }^{8}$ E.g., in Levinson v. Summerfield, Civil Action No. 976-55 (D.D.C. 1955), a suit was filed for an injunction compelling the return of a rare volume of Aristophanes' Lysistrata, which had been seized as obscene. Thereafter, the Postmaster General suggested that a "hearing" might be had, and when
} 
The practice of seizing, without prior notice or hearing, mail conceived to be obscene is currently pursued by the Post Office Department in patent disregard of the Court of Appeals for the District of Columbia. In Walker v. Popenoe, ${ }^{0}$ that court ruled that allegedly obscene mail must be carried and delivered unless and until such time as the Department should have already determined, upon fair notice and full hearing, that it was obscene; and that pending such a hearing and decision, and apart from other constitutional questions, seizure would be unlawful:10

We are not impressed with the argument that a rule requiring a hearing before mailing privileges are suspended would permit, while the hearing was going on, the distribution of publications intentionally obscene in plain defiance of every reasonable standard. In such a case the effective remedy is the immediate arrest of the offender for the crime penalized by this statute. Such action would prevent any form of distribution of the obscene material by mail or otherwise. If the offender were released on bail the conditions of that bail should be a sufficient protection against repetition of the offense before trial. But often mailing privileges are revoked in cases where the prosecuting officers are not sure enough to risk criminal prosecution. That was the situation here. Appellees have been prevented for a long period of time from mailing a publication which we now find contains nothing offensive to current standards of public decency. A full hearing is the minimum protection required by due process to prevent that kind of injury.

But the Department proceeds as though Walker v. Popenoe were but a bad dream, continuing to seize all mail conceived by it to be obscene-without prior notice and hearing.

This power of the Post Office Department to censor mail is presumed to be derived from title $\mathrm{I} 8$, section $\mathrm{I}_{4} 6 \mathrm{I}$, of the United States Code. ${ }^{11}$ It is of more than

this was refused, the volume was returned to the plaintiff. Thus, it would seem that the inordinate censorship powers enjoyed by the Post Office Department today are, perhaps, partly to be cxplained by the fact that interested parties, who ordinarily have little financial stake in the censored mail, infrequently challenge the Department in the courts.

${ }_{1} 49$ F.2d 5 Ir (D.C. Cir. 1945).

${ }^{10}$ Id. at $5 \mathrm{I} 4$.

11 "Every obscene, lewd, lascivious, or filthy book, pamphlet, picture, paper, letter, writing, print, or other publication of an indecent character; and-

"Every article or thing designed, adapted, or intended for preventing conception or producing abortion, or for any indecent or immoral use; and

"Every article, instrument, substance, drug, medicine, or thing which is advertised or described in a manner calculated to lead another to use or apply it for preventing conception or producing abortion, or for any indecent or immoral purpose; and

"Every written or printed card, letter, circular, book, pamphlet, advertisement, or notice of any kind giving information, directly or indirectly, where, or how, or from whom, or by what means any of such mentioned matters, articles, or things may be obtained or made, or where or by whom any act or operation of any kind for the procuring or producing of abortion will be done or performed, or how or by what means conception may be prevented or abortion produced, whether scalcd or unscaled; and "Every letter, packet, or package, or other mail matter containing any filthy, vile, or indecent thing, device, or substance; and

"Every paper, writing, advertisement, or representation that any article, instrument, substance, drug, medicine, or thing may, or can, be used or applied for preventing conception or producing abortion, or for any indecent or immoral purpose; and

"Every description calculated to induce or incite a person to so use or apply any such article, instrument, substance, drug, medicine, or thing- 
academic interest that this power can only be implied from the language of what is basically a criminal statute; that this power was never the subject of debate in either house of Congress when the statute was enacted; ${ }^{12}$ and that the constitutionality of this power has never been decided by the Supreme Court, ${ }^{13}$ although the power apparently has been exercised by the Department for some eighty years.

By virtue of this power, the Post Office Department may not only censor and prevent delivery of personal and individual shipments of books, magazines, and other printed matter, but may also gravely damage and disrupt the business of publishers and distributors. A hypothetical case may serve to point up its full significance. If the Post Office were to be presented today with ten thousand copies of tomorrow's Washington Post \& Times Herald for delivery and were to find it obscene (because, for example, the newspaper had commenced a serialized version of Simone de Beuvoir's widely-hailed work, The Second Sex) and act to exclude all copies of this edition from the mails, ten thousand mail subscribers would be deprived of their newspapers for that day. If the Post Office were to do this several days in a row, or several times a week or month, or during the entire run of the serialized version of the book, ten thousand subcribers would be subjected to repeated deprivations of their right to read the newspaper, while the newspaper would suffer damage, disruption of its business, and temporary loss of its Constitutiongiven right to freedom.

The exclusionary or seizure power is, however, but one of two broad means by which the Post Office Department may impede the distribution of sexually "immoral" literature and art.

\section{B. Blanket Stoppage of Mail Power}

In I950, Congress passed a new postal obscenity law ${ }^{14}$-apparently yielding to the

"Is declared to be nonmailable matter and shall not be conveyed in the mails or delivered from any post office or by any letter carrier.

"Whoever knowingly deposits for mailing or delivery, anything declared by this section to be nonmailable, or knowingly takes the same from the mails for the purpose of circulating or disposing thereof, or of aiding in the circulation or disposition thereof, shall be fined not more than $\$ 5,000$ or imprisoned not more than five years, or both.

"The term 'indecent', as used in this section includes matter of a character tending to incite arson, murder, or assassination." 62 STAT. 768 (1948), I 8 U. S. C. \$1461 (1952 Supp.).

${ }^{12}$ See Henry L. Mencken, Puritanism as a Literary Force, in A Book of PREFAces 197, 258 (I917).

${ }^{13}$ The Supreme Court has never tested the constitutionality of the Post Office Department's asserted power to censor obscene mail under the First Amendment. But cf. Donaldson v. Read Magazine, 333 U.S. 178 ( 1947 ), where the Court denied a contention that the constitutional guarantces of freedom of speech and freedom of press include complete freedom, uncontrollable by Congress, to use the mails for pcrpetration of swindling schemes.

Nor has the Court ever ruled on the constitutionality of the criminal aspect of the postal obscenity statute-i.e., it has never determined whether or not "obscene" is so vague and uncertain a standard as to be violative of due process. But cf. Doubleday v. Ncw York, 335 U.S. 848 (1948), where the Court divided, four to four, without opinion, as to whether a state obscenity statute imposing criminal sanctions, challenged on similar grounds, was constitutional.

For an excellent discussion and historical analysis of the constitutional issues involved in postal censorship, sce Deutsch, Frectom of the Press and of the Mails, 30 Mich. L. Rev. 703 (1938).

14 "Upon evidence satisfactory to the Postmaster Gencral that any person, firm, corporation, company, partnership, or association is obtaining, or attcmpting to obtain, remittances of money or property of any 
unremitting pressure from the Post Office Department and its empathetic congressional representatives, the standing Committees on the Post Office and Civil Service. As in the case of the original obscenity exclusionary laws, there were no congressional debates and no floor discussions whatever on the bill. The legislative history consists principally in a single letter from the then Postmaster General to the President of the Senate $^{15}$ which conveys no suggestion of the magnitude of the power later to be assumed by the Department under color of the new law. Though the reason for the bill was said to have lain in the need to plug a loophole in existing law, its true design was enormously to augment the Department's power over all persons using the mails. Carefully read, the bill that became law gave the Department the power to sever in toto and indefinitely ${ }^{16}$ all mail addressed to anyone it conceived to be dealing with obscenity. ${ }^{17}$ As a past Solicitor described the effect of such "stop" orders : ${ }^{18}$

They don't deliver any more mail of any kind to the particular defendant or respondent, as we call them, in those actions. In other words he can't even get a telephone bill or he can't get a postal card from his wife or daughter or anyone else.

Significantly, this power of the Post Office Department, literally applied, could be exercised against a person regardless of whether or not the mails were the channel being utilized for the distribution of the alleged obscenity. It could, for example, be enforced by the Department against a book publisher whose means of distribution was by private motor vehicle, but who had received payment through the mails for bcoks distributed or sold.

Moreover, this statute, again resembling the obscenity exclusionary statute, is silent as to a requirement for hearing prior to the issuance by the Post Office De-

kind through the mails for any obscene, lewd, lascivious, indecent, filthy, or vile article, mattcr, thing, device, or substance, or is depositing or is causing to be deposited in the United Statcs mails information as to where, how, or from whom the same may be obtaincd, the Postmaster General may-

(a) instruct postmasters at any post office at which registered letters or any other letters or mail matter arrive directed to any such person, firm, corporation, company, partncrship, or association, or to the agent or representative of such rerson, firm, corporation, company, partnership, or association, to return all such mail matter to the postmaster at the office at which it was originally mailed, with the word 'Unlawful' plainly written or stamped upon the outside thereof, and all such mail matter so returned to such postmasters shall be by them returncd to the senders thereof, under such regulations as the Postmaster General may prescribe; and

(b) forbid the payment by any postmaster to any such person, firm, corporation, company, partnership, or association, or to the agent or representative of such person, firm, corporation, company, partnership, or association, of any moncy order or postal note drawn to the order of such person, firm, corporation, company, partnership, or association, or to the agent or representativc of such person, firm, corporation, company, partnership, or association, and the Postmaster General may provide by regulation for the return to the remitters of the sums named in such money orders or postal notes." 64 STAT. 451 (1950), 39 U.S.C. $\$ 459$ a (Supp. 1952).

${ }^{15}$ See U.S. CODe CoNG. \& Ad. News 3007 (1950).

${ }^{16}$ In practice, however, the stop-order may be suspended upon a stipulation that objectionable mail will no longer be distributed.

${ }^{17}$ This obscenity stop-order power is similar to the much older fraud stop-order power. I7 STAT. 322, 323 (1872), as amended, 39 U.S.C. $\$ \$ 259,732$ (1946). Sec Donaldson v. Read Magazine, 333 U.S. 178 (1947); Cutler, The Post Office Department and the Administrative Procedure Act, 47 Nw. U.L. REV. 72-73 (1952).

${ }^{18}$ Testimony of Roy C. Frank, in Hearings before the Select Committce of the House of Representafites on Current Pornographic Materials, 82d Cong., $2 \mathrm{~d}$ Sess. 277 (1952). 
partment of blanket mail stop-orders. ${ }^{19}$ Although at first indisposed to read any hearing requirement into this statutory power given it by Congress, ${ }^{20}$ the Department apparently has seen the handwriting on the wall ${ }^{21}$ and has begun to issue rules and regulations designed to afford private parties the fair and full hearing contemplated by the Administrative Procedure Act of $1946 .^{22}$ Nevertheless, it has tried repeatedly to secure enactment of bills which would enable it to avoid such technicalities, impound all mail addressed to anyone it conceives to be engaged in an obscene business, and effectively avoid judicial review of its summary action. ${ }^{23}$ Nor does it appear that the Department is awaiting the word of Congress: in March 1954, it saw fit to issue, without notice or hearing, an order impounding all mail addressed to a seller and distributor of "publications, 'pin-up' pictures and novelties."24

The first court test of the Post Office Department's I950 obscenity stop-order power developed in 1953. The Department decided, after a hearing, that certain nudist publications of the Sunshine Book Company were obscene and ordered all mail addressed to the Company to be stopped, designated unlawful, and returned to the senders. Threatened with total disruption of its business, the Company immediately sued for and obtained a temporary restraining order and an injunction staying the Department's order. The Court of Appeals for the District of Columbia, in Summerfield $v$. Sunshine Book Co., ${ }^{25}$ upheld the lower court's action and ruled that the Department, under the statute, could lawfully issue a stop-order against only that mail addressed to the Company which was directly connected with specific issues of the Company's magazines found, after hearing, to be obscene. The court observed that, were the statute to be construed to authorize any wider order, "grave constitutional questions would then be presented."26 The court properly left to the Department the perhaps insuperable problem of identifying and segregating the tainted mail from all other mail.

As clear-cut an indictment of its practice of blanket stop-orders as was Summerfield v. Sunshine Book Company, the Post Office Department already seems of a mind to ignore it, as it did Walker v. Popenoe, supra. The Associate Solicitor for the Post Office Department recently was asked: "If you were to find that the Chevrolet Division of the General Motors Corporation had posted an obscene book,

${ }^{10}$ See note 14 supra. $\quad{ }^{20}$ See Cutler, supra note 17 , at $73-76$.

${ }^{21}$ See Wong Yong Sung v. McGrath, 339 U.S. 33 (1950); Riss \& Co. v. United States, 341 U.S. 907 (I95I); Cates v. Haderlein, 342 U.S. 804 (195I). Sce also Cutler, stipra note 17 , at 78.

${ }_{22}$ Ibid. It should be remembered, however, that these proviuions for a fair and full hearing have not been applied by the Post Office Department to its exclusionary or seizure actions. There is also evidence that the Department occasionally affords no hearing whatcver prior to impounding a publisher's mail. See Stanard v. Olesen, 74 Sup. Ct. 768, 98 L. Ed. $x 151$ (1954).

${ }^{23}$ See, e.g., H.R. 174, $84^{\text {th }}$ Cong., Ist Scss. (1955) (introduced by Mr. Recs, of Kansas). This bill and its predecessor in the sccond session of the Eighty-third Congress (H.R. 569 ), were vigorously opposed by the American Bar Association, which approved a bill introduced by Senator Carlson, of Kansas, S. 8, 84th Cong., Ist Sess. (1955). Neither of these bills passed.

${ }_{21}$ See Stanard v. Olesen, 74 Sup. Ct. 768, 98 L. Ed. II51 (1954).

${ }^{25} 221$ F.2d 42 (D.C. Cir., affirming, 128 F. Supp. 564 (D.D.C.), ccrt. denied, 74 Sup. Ct. 66r (1955).

${ }^{20}$ Id. at 48 . 
could you, as you construe your existing powers, issue an order to stop all mail sent to the Chevrolet Division?" The Associate Solicitor for the Post Office Department answered, "Yes."27

A closer case may better focus the point. The New American Library of World Literature, Inc., is properly considered to be a reputable publishing house. It receives payment for its books through the mails, although it does not use the mails as its principal means of distribution. The Library published, in 1953, a paper-back reprint edition of James Jones's novel, From Here to Eternity. A few copies of this edition were sent through the mails and were deemed obscene by the Post Office Department. The Library had also published, in 1952, a pocket-size reprint edition of Alberto Moravia's novel, Woman of Rome. A copy of this edition was sent through the mails and was similarly found obscene by the Department. Although the Department seized and refused to deliver these books, it never exercised the power it asserts (Summerfield $v$. Sunshine Book Co., notwithstanding). It did not, that is, upon hearing, find that the Library was "obtaining, or attempting to obtain remittances of money ... through the mails for any obscene . . . matter. . .." It did not order all mail addressed to the New American Library of World Literature, Inc., stopped and returned as "unlawful" to the senders. Had the Department exercised its apparent "option" to issue such an order and been upheld in such exercise, the business operations of the New American Library of World Literature, Inc., would have been paralyzed.

\section{II}

\section{IN THE NAME of Obscenity}

Were the Post Office Department able intelligently to perceive that quality of literature or art called "obscenity," its immense powers might approach justification. But the Department, in attempting to censor obscenity, seems to have failed as badly as any censor at any time anywhere. It may be that such disability is of the essence of censorship, and if this is so, the Department is to be criticized no more than any other censor. It is, no doubt, the function itself which should not exist.

The Post Office Department has no public Index Expurgatoris, perhaps because an Index is generally regarded to be characteristic of censorship, and because it is believed than an Index serves primarily to stimulate reading of the proscribed books. The Department does, however, have a card index containing the titles of most of the books and magazines which have been seized, censored, or suppressed through the years. ${ }^{28}$ Among these-and most literate persons will need travel no

${ }^{27}$ This exchange took place, and other similar remarks were made at an informal conference in Washington, D. C. between members of the House Post Office and Civil Service Committec, their representatives, representatives of the Solicitor's Office of the Post Office Department, and representatives of the American Bar Association, on May 23, 1955.

${ }^{28}$ Both the Post Office Department and the Customs Bureau apparcntly receive occasional requests for lists of books that they have banned. Such requests, however, are generally regarded as ill-motivated and are denied. 
further than their home bookshelves-are "obscene" works" by Ernest Hemingway, John O'Hara, James Jones, J. D. Salinger, Erskine Caldwell, Alberto Moravia, John Steinbeck, James T. Farrell, Norman Mailer, Calder Willingham, Vivian Connell, Charles Jackson, and Richard Wright. Titles by Somerset Maugham, Alexandre Dumas, Francois Voltaire, Guy de Maupassant, Emile Zola, and Leo Tolstoi have also been found obscene. There are works by Frank Harris and undistinguished novels in considerable number. But there also is found the literature of Aristophanes, Ovid, and Apuleus in unexpurgated translations. There are innumerable books on sexual love, sexual techniques, sexual deviations, sexual behavior, and contraception and comprehensive German works on erotic art and ceramics. And so are there works by Sigmund Freud, Kraft-Ebbing, Wilhelm Stekel, Margaret Mead, Bronislow Malinowski, and Simone de Beauvoir. The trouble with all of these books appears to be sex.

The Post Office Department is also found censoring and suppressing American and foreign nudist magazines (retouched and unretouched), nude photography magazines (retouched and unretouched), "girlie" and "burlesque" magazines, newsphoto magazines, crime and detective magazines, and "magazines for men." Many of these periodicals, as the Department is aware, may be purchased at a newstand a short walk from the building where Department censors sit.

Finally, the Post Office Department suppresses matter which must, for want of a more descriptive term, be described as "pornography," which includes hard-cover and soft-cover books of all sizes, art work, photographs, cartoon booklets, and films which vividly and/or "realistically" portray any and all manner and form of "carnal recreation."30 Such matter constitutes an almost negligible proportion of the literary materials seized by the Department. It is almost exclusively this relatively rare and readily identifiable type of "obscene" matter, however, which will cause the Department of Justice to institute criminal prosecutions for violation of the same postal obscenity law under which the Post Office Department censors. Probably 95 per cent of what is obscene to the postal censors is not obscene to the United States Attorneys or to the judges and juries who must be summoned in criminal prosecutions to adjudge criminal obscenity.

There are, undoubtedly, some who believe that a line can and should be drawn between such pornography, on the one hand, and legitimate literature and art, on the

\footnotetext{
${ }^{30}$ Most of the works in question have been ruled obscene by the Solicitor's Office of the Department; some, however, were seized as obscene by local postal employees who were subsequently reversed by the Solicitor's Office of the Department. In the author's view, both situations involve censorship, although the evil is obviously mitigated to some extent in the second. In compliance with the Department's wish not to stimulate the reading of such obscene books, the author is not identifying any titles.

${ }^{30}$ Curiously enough, even "pornography" may contain political idcas. The Post Office Department once seized four such blatantly pornographic "comic booklets" whose titles suggest their political overtones: Chambers and Hiss in Betrayal, Earl Browder in the Good Old U.S.A., Mahatma Gandhi in I'll Eat My Share, and Judith Coplon in Overpaid Lawyer. Another curious type of pornographic matter seized is the color "home movie" film of an apparently married couple cngaged in various types of "carnal recreation." Such films, when dispatched to and discovered by the developer and processor are apparently turned over to the Department of Justice for criminal prosecution.
} 
other, ${ }^{31}$ and that the Post Office Department can and should be made to distinguish between these kinds of printed materials and should be restrained from exercising its powers over the latter. Unfortunately, this position seems, from the standpoint of a free literature and art, vulnerable; it would almost certainly leave the Department censoring precisely what it now censors. For it is almost always pornography which is exhibited and paraded before the eyes of interested persons whenever censorship is proposed or defended. This is the material which Anthony Comstock is reported to have exhibited to the Congress which, in 1872 , passed "his" obscenity law. ${ }^{32}$ But Anthony Comstock shortly thereafter initiated prosecutions involving the poems of Walt Whitman and a play by G. B. Shaw. ${ }^{33}$ Moreover, it is inevitable, given a system of censorship, that the censor himself apply the criterion of censorship, whatever that criterion may be; and it comes close to the nature of bureaucracy, if not the nature of man, to expand jurisdictional criteria and thus jurisdiction and power. Censors cannot easily be controlled. There appears to be no way to compel the Department to censor only "pornographic" matter; judicial review comes only after the fact.

In this connection, it also should be recognized that "pornography" can be made to mean different things by different persons or groups. The House Select Committee on Current Pornographic Materials (the Gathings Committee), in 1952, construed "pornography" to include the greater part of all paper-back books sold everywhere at newsstands and drug counters. ${ }^{34}$ The National Organization for Decent Literature (NODL) concurred. ${ }^{35}$ The latest Senate Juvenile Delinquency Subcommittee hearings found subcommittee members and staff personnel tending to employ the word pornography to describe "suggestive" literature and "bondage" photographs, although previously the committee had limited its use of that term to the meaning above described. A trouble with the word "obscenity" is that it embraces, for some, the "cheese-cake" photographs to be found even in daily newspapers and "family" magazines. But the term "pornography," as above defined, would embrace so little matter that censors would have virtually nothing to do; yet, if not so defined, it would become synonymous with "obscenity." Were the Post Office Department to be ordered by court or Congress to censor only "pornography," it could only be expected to adopt a definition close to that suggested by the Gathings Committee and

${ }^{31}$ In at least one instance, the author has found this impossible-viz., where two comprehensive German works on erotic art and ceramics contained numerous reproductions of paintings and other art work by masters. It may further be noted that Casscll's Encyclopaedia of Literature (1953), in its section on "Erotic Literature," observes that "writers of literary distinction in all countries have often composed erotica," listing among others Goethe, Schiller, John Wilkes, and A. C. Swinburne. I id. 201, 202.

${ }^{32}$ See Heywood Broun and Margaret Leech, Anthony Comstock 88, 131 (1927).

${ }^{33} I d$. at 183,235 .

${ }^{34}$ See Report of the Select Committee of the House of Representatives on Current Pornographic Materials, H.R. REP. No. 25ro, 82d Cong., 2d Sess. I-3 (1952).

${ }^{35}$ See the testimony of Rev. Thomas J. Fitzgerald, in Hearings, supra note 19, at $47-48$.

${ }^{30}$ See Hearings before the Senate Subcommittee 10 Investigate Juvenile Delinguency, 84 th Cong, Ist Sess. passim (1955). 
the NODL, ${ }^{37}$ and continue to censor whatever literature or art violates its notions of appropriate sexual morality.

Thus, it is sufficient to note that for Post Office Department censors, the thread of "obscenity" can travel from "French postcards" to Laff to Esquire to Life; from Harris to O'Hara to Hemingway to Aristophanes; and from Lockridge to Malinowski to de Beauvoir to Freud. It can also travel from Monart Books to the Obelisk Press to the Fanfrolico Press to Signet to Doubleday to Knopf. ${ }^{3 s}$

III

\section{The Function of Postal Censorship of Obscenity}

The Post Office Department's justifications for its censorship of literature are little different from the reasons usually given to justify criminal prosecutions involving obscene literature. And yet, the Department's censorship activity would seem to require far greater justification, in as much as it violates-as no criminal obscenity statute can-three canons of free expression: "no previous restraints," "a fair and impartial trial," and "[no subjection] of all freedom of sentiment to the prejudices of one man ... [made] the arbitrary and infallible judge."39

The Post Office Department's justifications began with the philosophy of Anthony Comstock - the man credited with shaming Congress into passage of the basic postal obscenity law, whose views dominated the early enforcement of the law and whose mind molded the law's application for decades to come. The trouble with obscenity according to Comstock was that: ${ }^{40}$

The effect of this business on our youth and society, no pen can describe. It breeds lust. Lust defiles the body, debauches the imagination, corrupts the mind, deadens the will, destroys the memory, sears the conscience, hardens the heart and damns the soul. It unnerves the arm, and steals away the elastic step. It robs the soul of manly virtues, and imprints upon the mind of the youth, visions that throughout life curse the man or woman. Like a panorama, the imagination seems to keep this hated thing before the mind, until it wears its way deeper and deeper, plunging the victim into practices that he loathes. This traffic has made rakes and libertines in society-skeletons in many a household. The family is polluted, home desecrated, and each generation born into the world is more and more cursed by the inherited weakness, the harvest of this seed-sowing of the Evil one.

A powerful figure, feared and hated by many, Comstock was often subjected to attacks by what he was wont to describe as the nation's "secular press" and "a conspiracy of the blackest character . . . free lovers, convicts, and so-called liberals." ${ }^{\mathbf{1 1}}$ But Comstock's philosophy of obscenity, nevertheless, prevailed, and its fruits can

${ }^{37}$ The Post Office Department displayed complete sympathy with the objectives of the Cathings Committee, and vice versa. Sce the testimony of Roy C. Frank and Harry J. Simon, in Hearings, supra note 19 , at $274-88$.

${ }^{38}$ Information in the files of the Post Office Department, Washington, D. C.

${ }^{30} 4 \mathrm{Bl}$. Comm. *I5I, I52.

10 Anthony Comstock, Frauds Exposed (1880).

"1 Anthony Constock, Obscene Publications and Immoral Articles of Mail (n.d.). 
be found in numerous old court decisions $\mathrm{s}^{42}$ and in an occasional contemporary opinion. ${ }^{43}$ The language employed today by the Solicitor's Office of the Post Office Department when it serves notice of a book's seizure, though it be but a weak rendition of Comstock's vigorous prose, retains the essential argument. One of the most recent examples is found in a letter from the Solicitor to a rare-book dealer who had ordered, through the mails, a rare-edition copy of Aristophanes' Lysistrata. The critical portion of the letters reads as follows: ${ }^{44}$

Examination of this "Lysistrata" shows that it contains numerous passages which are plainly obscene, lewd and lascivious in character which are well calculated to deprave the morals of persons reading same and almost equally certain to arouse libidinous thoughts in the minds of the normal reader. The effect of the book is intensified and heightened by the indecent and lascivious character of the illustrations.

This condemnation is typical and, rudimentary as it may seem, contains the whole theory of the function of the Post Office Department's obscenity operations: to protect the morals of the recipient and "normal reader" of literature sent through the mails, and to prevent the arousal of libidinous thoughts in the mind of the recipient and "normal reader." Whether the condemned material be pornography or Attic comedy, these are the basic justifications, urged on the Department by those who appear to possess what may, for want of better nomenclature, be called the "comstockian mind."

The "comstockian mind" demands that the government censor obscene literature and art on the ground that only by such censorship will the reader's mind be saved from libidinal moral depravity. The question is never asked how it can be a proper function of a democratic government to intrude upon individual morality and compel the individual to be saved from himself. The individual reader is never asked whether he wishes to be "saved" by governmental intervention. Nor is the question asked whether the reader might not prefer to be rescued, if at all, by his priest or psychoanalyst. Such questions are not asked because they are basically irrelevant to the pressure for postal censorship: the psychological need of the "comstockian mind" to save itself from libidinal corruption.

Most persons, including the "normal reader," have little difficulty in dealing with erotic or obscene literature and art. If libidinal thoughts are aroused, as charged, by an obscene book (or, for that matter, by an attractive woman), they are accepted and entertained, or negated and rejected, in one way or another: there is no painful moral conflict or emotional holocaust with a resultant sense of "moral depravity."

A neurotic person, on the other hand, may be deeply troubled by the spectre of obscene literature or art-fearing his inability to cope with libidinous thoughts, how-

${ }^{42}$ See, e.g., United States v. Limehouse, 285 U.S. 424 (1932); Rosen v. United States, 16 I U.S. 29 (1896); United States v. Clarke, 38 Fed. 732 (E.D. Mo. I889); United States v. Martin, 50 Fed. 918 (W.D. Va. 1892).

${ }^{33}$ See, e.g., Besig v. United States, 208 F.2d 142 (9th Cir. 1953).

* Letter from Abe McGregor Goff to Harry A. Levinson, Nov. 2, 1954, in author's filc. 
ever aroused. Feelings of guilt, shame, or disgust may descend demanding annihilation of the aroused erotic impulses, leaving in their wake the more generalized feeling of "moral depravity." One method by which such a person attempts to cope with his fear of obscene literature and art and its attendant pangs is through the psychological mechanism of "projection." If the painful psychic conflict can be projected outward onto the external world, it may be perceived as arising in other persons and not oneself. This is comforting not only because the problem then becomes someone else's, but also because external authoritarian mechanisms can be brought to bear upon and suppress the dangerous erotic stimuli. This is where the federal government enters. If the Post Office Department can be made to censor, suppress, and condemn the obscene matter, the "other" persons will be "saved" from certain depravity, and the "comstockian mind" will be rescued from its crisis of fear and anxiety and its precarious moral equilibrium reinforced. ${ }^{\mathbf{4 5}}$

What the "comstockian mind" cannot or will not recognize is that the normal reader feels no threat in this situation and has need for no governmental intervention to save himself from his own impulses or protect himself from his own ideas. What the Post Office Department, for its part, cannot or will not recognize is that its censorship activity rescues from "moral depravity" not the normal reader's mind, but the neurotic "comstockian mind," and additionally serves to vindicate the sexual morals of this mind. What the American public has not yet recognized is that by sanctioning governmental censorship, it permits neurotic minds to project their collective neurosis and their sexual mores onto all of American literature and art. Further, it lends its weight to the morally insidious and politically dangerous proposition that the average American man is, and is expected by his government to be, psychologically incapable of controlling his own impulses or sorting out his own thoughts. Whenever a piece of literature or art, of whatever kind, is seized and condemned by the Post Office Department, Americans are advised by their government that their minds and souls are too weak to withstand, accept, or reject such thoughts as are presented; that they require their government to save them from inner dissolution, corruption, or depravity. Exorcism of this authoritarian attitude rather than obscene literature and art, is what is indicated if we are to mature into the free and democratic community toward which we claim to aspire. It would appear to be an error of major proportions for the government to canonize the sexually neurotic, fearful, guilt-ridden man-by codifying his mind into moral law. ${ }^{46}$

\footnotetext{
"For an excellent but brief elaboration of this thesis, sce Joel Rinaldo, Psychoanalysis of the "REFormer" (192I).

${ }^{16}$ It is readily apparent from the nature of some of the books which have been found obscene by the Department that even non-libidinal, non-fictional literature can violate the Department's conception of proper sexual morality. Thus are the works of psychiatrists, anthropologists, and social philosophers occasionally censored. Non-libidinal fictional literature may also be censored by the Post Office Department because violative of the decreed sexual mores. Two "marked" passages among over fifty similarly marked passages from the book, The Woman of Rome, may suffice to illustrate how fiction may become obscene by virtue of the presentation of "immoral" sexual views:
}

"I am a whore,' I said aloud at last to see what effect the words would have on me. They did 
Man will reach his true salvation by himself or not at all. Though he can and may be helped by others, he cannot and will not be saved by anyone else. The postal obscenity laws, as applied by the Department, are designed to save men -from the thoughts of others and from their own thoughts. To this end, the postal laws bring to bear on the individual the coercive powers of the state. Nothing could be more ill-conceived or futile. Nothing could be more repugnant to the ends of freedom of thought and freedom of expression.

not seem to have any cffect so shutting my eyes I fell asleep almost immediately."

" 'They have a bath after they've made love, don't they?'

'How should I know what they do?' he answered with a shrug. . . ." 